\title{
RELATIONSHIP BETWEEN LOGISTICS INFRASTRUCTURE AND TRADE: EVIDENCE FROM SPANISH REGIONAL EXPORTS
}

\author{
BENSASSI ${ }^{A}$, S., MÁRQUEZ-RAMOS ${ }^{B}$, L., MARTíNEZ-ZARZOSO ${ }^{\text {B,C }}{ }^{\text {, I. AND SUÁREZ-BURGUET }}{ }^{B}$, C.

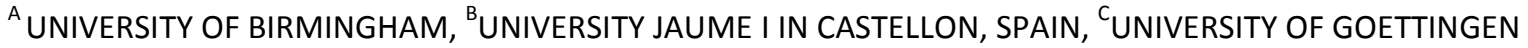 \\ PREPRINT VERSION (PUBLISHED IN TRANSPORTATION RESEARCH PART A, 2015)
}

\begin{abstract}
Geographical factors and transport infrastructure are two of the key determinants that influence international competitiveness. In this sense, the quality of such infrastructure and how widespread it is, the distribution and capacity of logistics facilities in a country, as well as the number of private operators and their degree of specialisation, all play an increasingly important role in the design of business strategies aimed at increasing a country's share of the international market. Until recently, however, availability and access to logistics services have been considered secondary factors when defining business competitiveness. This paper estimates an augmented gravity model of trade that specifically includes logistics and transport infrastructure indicators as explanatory variables. The model is estimated by using bilateral exports from 19 Spanish regions to 64 destinations (45 countries and 19 Spanish regions) with data for the period 2003 to 2007. The findings show that logistics is indeed important for the analysis of trade flows in goods and they highlight the importance of logistics measures at the regional level. In particular, the number, size and quality of logistics facilities positively influence export flows.
\end{abstract}

Keywords: Logistics; transport infrastructure; gravity equation; regional exports; Spain.

JEL Classification: F14, H54, R11, R42

\section{INTRODUCTION}

Geographical factors and transport infrastructure are among the most relevant determinants that affect international competitiveness. In this regard, the geographical distance between a region and its main trading partners, together with trade facilitation, ${ }^{1}$ are often considered the factors that explain a region's competitive position in international markets (Wilson et al, 2005; Martínez-Zarzoso and MárquezRamos, 2008; Márquez-Ramos et al, 2012; Persson, 2012; Márquez-Ramos and Aparisi-Caudeli, 2013). However, it is important to take into account other physical and geographical aspects that the literature on the topic has largely neglected, namely factors related to access to logistics services. The quality of logistics infrastructure, the distribution of intermodal facilities within countries, together with the number of logistics operators and their specialisation are considered increasingly important as a means of enhancing international competitiveness and expanding the

\footnotetext{
${ }^{1}$ The World Trade Organization (1998) defined trade facilitation as the simplification and harmonisation of international trade procedures where trade procedures are the activities, practices and formalities involved in collecting, presenting, communicating and processing data required for the movement of goods in international trade. For example: the reduction in the number of documents required to export/import, those procedures that reduce the time to export/import, or improvements in management information systems.
} 
market share of companies. Within this context, Jacks and Pendakur (2010) state that the most commonly-held perception is that the growth of world trade is strongly associated with technological improvement in the communication and transport sectors. They focus on the United Kingdom to analyse whether transport revolutions over the period 1870-1913 had an effect on trade. Although their results are unable to confirm whether the maritime transport revolution was a primary driver of the latenineteenth-century global trade boom, ${ }^{2}$ the authors point out that "the differential decline in overland and maritime freight rates across countries might tell a different story". ${ }^{3}$ More recently, the findings of Bernhofen et al (2013) suggest that containerisation ${ }^{4}$ had a considerable effect on world trade over the period 1962-1990. They state that containerisation not only affected the operation and relocation of ports but the entire transportation industry and it has also gone hand-in-hand with the creation of the modern intermodal transport system, facilitating increases in shipping capacities and reductions in delivery times through intermodal cargo movements between ships, trains and trucks.

Indeed, right from the outset, the European Community provided a common transport policy, which was set out in the 1992 White Paper at the same time as the Maastricht Treaty on European Union (EU). According to the new policy, the new objective for transport policy was the creation of a trans-European transport network. In order to achieve this goal, Europe aimed at improving the existing transport infrastructure and building the trans-European transport network by means of various actions in which logistics facilities played a vital role (Alamá-Sabater et al, 2013). ${ }^{5}$ With regard to EU and Spanish policies, six main guidelines for action were established for the period 2007-2013 with respect to the expansion and improvement of transport infrastructures (ECORYS Nederland BV, 2006): 1) give priority to projects of European interest; 2) complementary investment in secondary connections; 3) support for rail infrastructure; 4) promote environmentally sustainable transport networks; 5) improve the connectivity of landlocked territories to the Trans-European network. In this respect, the development of secondary links, with a focus on intermodality and sustainable transport, should be promoted. In particular, harbours and airports should be connected to their hinterland; and 6) development of the "motorways of the sea" (MoS) and short-sea shipping as a viable alternative to longdistance road and rail transport. With respect to this last guideline, one of the main advantages for Spain in Europe would be the development of the MoS, given Spain's strategic position in maritime corridors. To this end, the Spanish Association for the Promotion of Short-Sea Shipping was set up in 2002. Since its constitution, this Association has consolidated a series of activities that have contributed to promoting short distance shipping and the coordination between the different agents forming part of the same sea-land chain (Puertos del Estado, 2014).

Concerning overland transport, the Pyrenees form a major natural barrier between the Iberian Peninsula and the rest of Europe. Unlike the situation in the Alps, the Pyrenees, with the exception of the coastal strips, do not currently possess any

\footnotetext{
${ }^{2}$ From 1870 to 1913 , maritime freight rates fell on average by $50 \%$ as a result of productivity growth in the shipping industry, while global trade increased by $400 \%$.

3 Page 753.

${ }^{4}$ As their data provides information on both port and railway containerisation, their analysis covers the main modes of international transport.

${ }^{5}$ Such as modernising infrastructure, completing links between existing transport nodes, or using more efficient multimodal services to improve connections between different modes of transport.
} 
significant road or rail infrastructure that connects Spain with France. Nonetheless, the Ministers of Transport of the EU have refused to include the central corridor of the Pyrenees on the list of priority infrastructure projects co-financed by the EU. The proposal made by the European Commission (2011) regarding the future of the European Transport Network for the 2014-2030 timeframe includes the Mediterranean Corridor, which will link Algeciras with Portbou, as a priority project. This corridor will connect the Iberian Peninsula to the rest of Europe and will principally benefit Spanish trade and in turn Spanish economic activity.

As regards Spain's geographical location, we can identify two contrasting realities. On the one hand, Spain is located on the periphery of Western Europe and this constitutes a clear disadvantage in the longer-distance European freight markets, partly due to the different railway track gauge used in Spain and France, which obviously makes transit across their common border very challenging. On the other hand, Spain is the natural gateway for trade between Europe and the countries in Northern Africa and Latin America, and it also enjoys an excellent strategic advantage on the East-West Trade Route via the Mediterranean Sea. This paper hypothesises that logistics improvements will greatly benefit Spain and help the country to gain advantages over other competing Mediterranean countries. Consequently, it will be able to position itself as the gateway to Europe. Nonetheless, Rodrigue and Notteboom (2010) argue that in Western Europe the hinterland is intense not only along the coastline but also inland. The hinterland is accessed from coastal gateways by medium-distance corridors involving a variety of combinations of transport modes. Therefore, the present paper also hypothesises that whether the benefits of Spain's geographical location ultimately outweigh the disadvantages depends to a great extent on the quality of logistics infrastructure. In favour of the argument that logistics enhance competitiveness, previous research that assessed the impact of the trans-European road network using a vector geographic information system showed that the planned new roads would improve the levels of accessibility to economic activity centres, thus reducing the friction of distance and bringing peripheral regions closer to central ones (Gutiérrez and Urbano, 1996).

The present study simultaneously analyses Spanish domestic and foreign trade in goods. The contribution this paper makes consists of estimating the empirical relationship between logistics and trade. The baseline hypothesis is that improvements in transport infrastructure and in particular in logistics facilities reduce trade costs and boost flows of goods among countries and regions.

In order to test this hypothesis, we estimate a model that includes logistics and transport infrastructure indicators as explanatory variables within the framework of a methodology based on augmented gravity equations. More explicitly, we focus on the role of hardware and software logistics on trade. Hardware indicators represent overland and maritime infrastructure endowments, and also how well countries are connected in the world economy, while software indicators reflect the logistics management performance (Coca-Castaño et al, 2005).

The main results of this study confirm the relative importance of the logistics factors analysed when compared to other variables that are traditionally considered in standard trade models.

The article is organised as follows. The second section presents a review of the literature, which identifies a series of indicators that have been used to measure logistics and transport infrastructure. The third section describes the state of the logistics sector in Spain. In the fourth section, we examine the determinants of 
bilateral trade and specify the empirical model for trade flows between Spanish Autonomous Regions (hereafter referred to as regions) and Spanish international trade. The fifth section details the results obtained and, finally, the last section presents the conclusions of this research.

\section{LoGistics PERFORMANCE AND TRADE}

The lack of a widely-accepted definition of the logistics industry, both at national and regional level, may explain the relative shortage of analyses that directly quantify the impact this sector has on international trade. Most existing studies only consider the effect of individual aspects of the logistics chain on international trade. In this regard, studies such as Limão and Venables (2001), Martínez-Zarzoso et al (2003), Sánchez et al (2003), Clark et al (2004), Micco and Serebrisky (2004), Wilson et al (2005), Coca-Castaño et al (2005) and Márquez-Ramos et al (2011) specifically focus on transport infrastructure indicators.

Limão and Venables (2001) focus on the impact of a country's infrastructure and transport costs on bilateral trade. They construct an index that estimates the level of infrastructure in each country on the basis of four indicators, namely kilometres of roads, paved roads and railways, and the number of telephone lines. The authors also obtained transport costs data from two sources. The first, based on primary data, includes freight costs, obtained directly from logistics companies, of moving a standard container from Baltimore to 64 destinations. The second source is international trade statistics (CIF-FOB ratios). The main results obtained using the first data source indicate that infrastructure is an important determinant of transport costs, particularly for landlocked countries. The estimates using CIF-FOB ratios based on bilateral trade data confirm the importance of infrastructure. In particular, a deterioration of infrastructure from the median to the 75th percentile, increases transport costs by $12 \%$ and reduces trade by $28 \%$. The estimated elasticity of trade flows with respect to transport costs is around -3 . The results of the specific analysis of trade flows in Africa indicate that the relatively low level of trade is due to a lack of appropriate infrastructure.

A limited number of studies have analysed the impact of infrastructure on trade in specific branches of activity, as is the case with Martínez-Zarzoso et al (2003), who analyse the ceramic tile industry in Spain. These authors study the effect of transport costs on Spanish ceramic exports. Infrastructure is considered a determinant of transport costs and is incorporated into the estimated model using a similar index to that in Limão and Venables (2001). Their results confirm that a 1\% improvement in infrastructure in the destination country reduces transport costs by $0.14 \%$ and in particular show that a $1 \%$ increase in the infrastructure score of the destination country leads to a $1.65 \%$ increase in ceramic tile exports.

Among the infrastructure necessary to facilitate trade, the efficiency of ports has received specific attention in Sánchez et al (2003) and Clark et al (2004). These authors show that port efficiency is relevant for a large proportion of transactions related to international trade. This is true not only for the activities that depend directly on port infrastructure, such as pilotage, towing, stevedoring or even freight storage and depositing, but also for other administrative activities, including fulfilling customs requirements. Using a measure of port efficiency ${ }^{6}$ provided by the 1999

\footnotetext{
${ }^{6}$ This variable is based on a one-to-seven index (seven being the best score).
} 
Global Competitiveness Report of the World Economic Forum, the results obtained by Clark et al (2004) indicate that this variable has a marked impact on international trade through transport costs. More specifically, they find that an improvement in port efficiency from the 25th percentile to the 75th percentile reduces maritime transport costs by more than $12 \%$, equivalent to 5,000 miles in terms of geographical distance, and would entail a $25 \%$ rise in bilateral trade. Similarly, Sánchez et al (2003) measure port efficiency using data on efficiency in time, port productivity and vessel length of stay at port obtained from surveys sent to 55 Latin American port terminals in 1999. The results obtained indicate that an increase in port productivity reduces transport costs. Also, for the year 1999, Coca-Castaño et al (2005) investigate the effects of logistics performance on international trade flows by separately analysing hardware and software logistics indicators. Their results indicate that improvements in both hardware and software logistics indicators foster international trade.

Concerning port infrastructure, Núñez-Sánchez and Coto-Millán (2012) calculate an index of technical efficiency for Spanish ports and prove that despite this index averaging $78.6 \%$ for the port system as a whole (for the period 1986-2005), there are considerable differences between ports, those in Valencia, Tenerife and Algeciras being the most efficient. This study uses data gathered from the Annual Reports of Puertos del Estado (several years). Other related studies that have also used this data source, as we have in the sensitivity analysis in the present paper, are González and Trujillo (2008), Núñez-Sánchez et al (2011) and Márquez-Ramos and AparisiCaudeli (2013).

Other authors focus on alternative modes of transport. For example, Micco and Serebrisky (2004) analyse US air imports and Wilson et al (2005) study how air and port efficiency influences international trade. Both studies confirm that greater airport efficiency in exporting and importing countries increases international trade.

A more recent study by Márquez-Ramos et al (2011) explores the determinants of maritime transport costs and their effect on international trade for the case of Spanish exports. These authors show the important effect that connectivity - a more general concept than transport infrastructure - has on trade flows. Five variables are proposed to measure connectivity between countries: the structure of the maritime route, port infrastructure supply in the origin country, port infrastructure supply in the destination country, structure of machinery and structure of services. The results indicate that all five significantly influence trade flows, in addition to their overall influence on trade.

At this point, it is worth highlighting two clearly separate strands of research in the logistics-trade literature. On the one hand, a considerable number of studies have focused on the effect that different logistics-related factors have on international trade, using the empirical framework of a gravity equation (for example, MartínezZarzoso et al, 2003; Wilson et al, 2005; Márquez-Ramos et al, 2011). On the other hand, some studies have attempted to measure the level of logistics performance achieved by different countries or regions (for example, Solakivi et al, 2009). Table 1 summarises the main results of studies in the first strand, listing information about the main contribution, the data and methodology used and the logistics indicator investigated in each case.

The present study contributes to both strands of the literature by constructing logistics measures at regional level in Spain and by analysing the role that these measures play in international trade by means of gravity equations. 
In recent years, a number of authors have developed and used alternative transportation-geography measures based on different frameworks, such as network analysis. An example is the centrality index used by Wang et al (2011) to examine the overall network structure and centrality of individual cities in the air transportation network of China. Unfortunately, the structure of the data in the present research does not allow the transitivity of bilateral trade flows to be taken into account, as we only have origin-destination information on trade flows. However, the importance of this issue is acknowledged and requires further research. 
TABLE 1. SUMMARY OF STUDIES THAT ANALYSE THE EFFECT OF LOGISTICS ON TRANSPORT COSTS AND/OR TRADE

\begin{tabular}{|c|c|c|c|c|}
\hline Authors & Data sample & Model & Logistics indicators & Observations \\
\hline $\begin{array}{l}\text { Limão and Venables } \\
\text { (2001) }\end{array}$ & $\begin{array}{l}\text { Source: transport costs for } 64 \\
\text { destinations obtained from } \\
\text { logistics companies and } \\
\text { international trade statistics } \\
1990 \text { data for } 103 \text { countries }\end{array}$ & $\begin{array}{l}\text { Determinants of } \\
\text { transport costs and } \\
\text { trade (gravity) }\end{array}$ & $\begin{array}{l}\text { Index that estimates the level of infrastructure } \\
\text { development in each country on the basis of a } \\
\text { combination of kilometres of roads and } \\
\text { railways, and the number of telephone lines } \\
\text { (index "á la Limão and Venables") }\end{array}$ & $\begin{array}{l}\text { If infrastructure deteriorates from the median to the } \\
75 \text { th percentile, transport costs increase by } 12 \% \text { and } \\
\text { trade is reduced by } 28 \% \\
\text { The elasticity for trade flows in regard to trade costs } \\
\text { is approximately }-3\end{array}$ \\
\hline $\begin{array}{l}\text { Martínez-Zarzoso et al } \\
\text { (2003) }\end{array}$ & $\begin{array}{l}\text { Source: interviews held with } \\
\text { Spanish logistics operators, } \\
1999 \text { data on Spanish ceramic } \\
\text { exports to } 76 \text { destinations }\end{array}$ & $\begin{array}{l}\text { Determinants of } \\
\text { transport costs and } \\
\text { trade (gravity) }\end{array}$ & $\begin{array}{l}\text { Similar index to that in Limão and Venables } \\
\text { (2001), i.e. taking information on roads, paved } \\
\text { roads, railroads and telephones }\end{array}$ & $\begin{array}{l}\text { A } 1 \% \text { improvement in infrastructure in the destination } \\
\text { country reduces transport costs by } 0.14 \% \\
\text { A } 1 \% \text { increase in the infrastructure score of the } \\
\text { destination country generates a } 1.65 \% \text { increase in } \\
\text { ceramic tile exports }\end{array}$ \\
\hline Sánchez et al (2003) & $\begin{array}{l}\text { Source: surveys sent to } 55 \text { Latin } \\
\text { American port terminals in } 1999\end{array}$ & $\begin{array}{l}\text { Determinants of } \\
\text { waterborne transport } \\
\text { costs }\end{array}$ & $\begin{array}{l}\text { Port efficiency factors: } \\
\text { Efficiency in time } \\
\text { Port productivity } \\
\text { Vessel length of stay at port }\end{array}$ & $\begin{array}{l}\text { Increasing port efficiency leads to a reduction in } \\
\text { transport costs }\end{array}$ \\
\hline Clark et al (2004) & $\begin{array}{l}\text { Source: U.S. Import Waterborne } \\
\text { Databank and World Economic } \\
\text { Forum } \\
\text { Years } 1996,1998 \text { and } 2000 \\
\text { Transport cost indexes for } 43 \\
\text { countries }\end{array}$ & $\begin{array}{l}\text { Determinants of } \\
\text { trade (gravity) }\end{array}$ & $\begin{array}{l}\text { Port efficiency based on surveys completed by } \\
\text { representative firms of each country. The } \\
\text { specific question is "port } \\
\text { facilities and inland waterways are extensive } \\
\text { and efficient" (1-strongly disagree, } \\
\text { 7-strongly agree) }\end{array}$ & $\begin{array}{l}\text { An improvement in port efficiency from the 25th } \\
\text { percentile to the } 75 \text { th percentile reduces maritime } \\
\text { transport costs by more than } 12 \% \text {, which is the } \\
\text { equivalent of } 5,000 \text { miles in terms of geographical } \\
\text { distance and would entail a } 25 \% \text { rise in bilateral } \\
\text { trade }\end{array}$ \\
\hline $\begin{array}{l}\text { Micco and Serebrisky } \\
\text { (2004) }\end{array}$ & $\begin{array}{l}\text { Sources: the U.S. Imports of } \\
\text { Merchandise Database and the } \\
\text { U.S. Department of Commerce } \\
\text { Period: } 1990-2001\end{array}$ & $\begin{array}{l}\text { Determinants of air } \\
\text { transport costs }\end{array}$ & $\begin{array}{l}\text { Airport infrastructure, regulatory quality and } \\
\text { liberalisation of air cargo markets }\end{array}$ & $\begin{array}{l}\text { An improvement in airport infrastructure from the } \\
25 \text { th to } 75 \text { th percentiles reduces air transport costs } \\
\text { by } 15 \% \text {. A similar improvement in the quality of } \\
\text { regulation reduces air transport costs by } 14 \% \text {. Open } \\
\text { Skies Agreements further reduce air transport costs } \\
\text { by } 8 \%\end{array}$ \\
\hline Wilson et al (2005) & $\begin{array}{l}\text { Source: Commodity and Trade } \\
\text { Database of the United Nations } \\
\text { Statistics Division } \\
\text { Period: } 2000-2001 \\
75 \text { countries }\end{array}$ & $\begin{array}{l}\text { Determinant of trade } \\
\text { (gravity) }\end{array}$ & $\begin{array}{l}\text { Four categories of trade facilitation: (air and } \\
\text { maritime) port infrastructure, customs } \\
\text { environment, regulatory environment and e- } \\
\text { business infrastructures }\end{array}$ & $\begin{array}{l}\text { Improvement in all four forms of trade facilitation in } \\
\text { the 'below-average' countries 'halfway' to global } \\
\text { average, yields an increase in global trade of } \$ 377 \\
\text { billion }\end{array}$ \\
\hline Coca-Castaño et al (2005) & $\begin{array}{l}\text { Source: international trade } \\
\text { statistics } \\
1999 \text { data for } 65 \text { countries }\end{array}$ & $\begin{array}{l}\text { Determinants of } \\
\text { trade (gravity) }\end{array}$ & $\begin{array}{l}\text { Hardware infrastructure: endowment of land, } \\
\text { port and technological infrastructure. } \\
\text { Software infrastructure: Technological } \\
\text { Achievement Index (UNDP, 2001) and index of } \\
\text { economic freedom (Miles et al, 2004) }\end{array}$ & $\begin{array}{l}\text { The higher the (hardware and software) logistics } \\
\text { indicators, the higher the bilateral trade }\end{array}$ \\
\hline $\begin{array}{l}\text { Márquez-Ramos et al } \\
\text { (2011) }\end{array}$ & $\begin{array}{l}\text { Source: TradeTrans } \\
\text { Sectoral exports from } 5 \text { Spanish } \\
\text { ports to } 17 \text { countries } \\
\text { Year } 2003\end{array}$ & $\begin{array}{l}\text { Determinants of } \\
\text { maritime transport } \\
\text { costs and trade } \\
\text { (gravity) }\end{array}$ & $\begin{array}{l}\text { Dimensions of the connectivity index: } \\
\text { Maritime route structure; infrastructure supply } \\
\text { at port of origin; infrastructure supply at port of } \\
\text { destination; equipment structure; service } \\
\text { structure }\end{array}$ & $\begin{array}{l}\text { The dimensions of the connectivity index are } \\
\text { relevant on freight rates. A } 10 \% \text { decrease in ad- } \\
\text { valorem freight rates increases international trade by } \\
4.4 \%\end{array}$ \\
\hline
\end{tabular}




\section{LOGISTICS IN SPAIN: DEFINITION AND MEASUREMENT}

In $2009,74 \%$ of total Spanish exports were bound for European countries and $65 \%$ of total Spanish imports came from European countries (INE, 2011). Despite the distance separating Spain from the centre of economic activity in Europe and the fact that it is isolated from the rest of the continent, alongside Portugal on the Iberian Peninsula, Spain's main trading partners are EU countries. Only two main roads and two railway routes connect Spain to France and, therefore, to the rest of Europe through the Pyrenees (Hendaya/Irún and Cerbère/Portbou). At the same time, Spain is a mountainous country with an average altitude of 610 metres. These conditions make access to the main ports and connectivity with the European transport network via France particularly important for Spanish exporters and importers.

Logistics infrastructure is of vital importance to be able to efficiently channel the various freight flows to their points of departure from or entry into Spain. The project entitled Red Española de Plataformas Logísticas (Spanish Network of Logistics Facilities or RELOG) ${ }^{7}$ has compiled up-to-date information on Spanish logistics facilities for the first time.

A number of different definitions of logistics and logistics measures have been considered in the related literature. In particular, Coca-Castaño et al (2005) asserts that logistics aspects have hardware and software components. The first component includes factors that improve a country's access and connections to the rest of the world (logistics hardware), whereas the second comprises factors that influence appropriate logistics management (logistics software). Some international institutions however use other measures. More specifically, the World Economic Forum focuses on port efficiency, while the World Bank provides the Logistics Performance Index (LPI) based on surveys completed by experts in logistics. ${ }^{8}$ The main shortcoming of these indicators is that they are based on definitions and measures at a country level. In this paper, we focus instead on the role of logistics facilities at a regional level.

Logistics facilities are physical locations where logistics activities are performed, in other words, places where goods can be stored or transferred to different modes of transport and where their transportation can be organised. According to the European Association of Freight Villages, a logistics platform is a defined area within which all activities relating to transport, logistics and the distribution of goods, both for national and international transit, are carried out by various operators. It is run by a single body, either public or private, and is equipped with all the public facilities to carry out these operations. In order to be included in this study, it was stipulated that the facility must be a multi-user facility rather than a private company facility.

We focus firstly on the importance of intermodality and on the abovementioned definition of logistics facility and then, all the identified nodes are examined in

\footnotetext{
${ }^{7}$ Project entitled "Defining a Spanish Network of Logistics Platforms" (RELOG) financed by the Spanish Ministry of Transport (P 21/08).

${ }^{8}$ According to the LPI (World Bank, 2010), although Spain is relatively well located with regard to the rest of the world, this is not so much the case when compared to the EU. Considering the pre-2004 EU countries, Spain is ranked ahead of only Greece and Portugal and registers very similar scores to those of the Eastern European countries that have recently joined the EU. Spain's competitors as potential entry ports for traded goods, located in Germany, the Netherlands and Belgium, lead the ranking in terms of logistics.
} 
the main econometric analysis. However, it is worth noting that locations that only handle freight are not included in the inventory, whereas others which are not very active in the market are included. With this limitation in mind and taking into account the data available, we focus secondly on ports, in order to delve deeper into the relative importance of freight facilities in terms of international competitiveness.

The locations that we consider logistics platforms are, using the normal terminology of the sector, dry ports, logistics facilities, logistics zones, centres for exchanging goods, intermodal centres, logistics centres, transport centres, ports, freight terminals, boarding centres and freight terminals at airports (see Appendix B). The characteristics that interact in each facility are: the international-interregional link; transit flows; intermodality; stocking facilities; special logistics requirements for special products, etc. ${ }^{9}$

Furthermore, we have also obtained the number of modes of transport and operations carried out at each facility in order to build a Regional Logistics Performance Index (regional LPI) ${ }^{10}$ by calculating for each region the simple mean of the standardised value of the following four variables: number of facilities, logistics area available, number of modes of transport ${ }^{11}$ and number of logistics operations performed at existing logistics facilities in each region. ${ }^{12}$ This index, for which high scores indicate a high level of regional logistics performance (see Table A.3 in Appendix A), paints a similar picture of the state

\footnotetext{
${ }^{9}$ Andalusia, the most populated region in Spain and the second largest, has the highest number of logistics facilities. The large number of facilities in Andalusia must be assessed in terms of specialisation and intermodal development, bearing in mind the heterogeneity this region displays compared to other more advanced Spanish regions in terms of logistics. This is particularly important when considering surface area as an indicative variable, as the surface area used to move vessels or aircraft in facilities such as ports and airports, or even zones devoted to security and controlling approach operations, may be treated as an area of logistics activity. With regards to the share of surface area devoted to logistics activities in each Spanish region relative to the total for the country as a whole, the most populated regions (Andalusia, Catalonia, Madrid and Valencia) also devote the most surface area to logistics facilities. Extremadura and Castile and Leon, in contrast, are found lacking in terms of square metres used for logistics activities. By calculating the average surface area devoted to logistics (logistics surface area divided by the number of facilities in each region), Madrid, Aragon and Andalusia record the highest scores, due to the presence of very large logistics facilities in these three regions (the Zaragoza Logistics Centre in Aragon, the Madrid Barajas Centre in Madrid and the Port of Algeciras in Andalusia), which raise the average size of existing facilities in each region. The Balearic and Canary Islands also have large facilities linked to their ports. The average surface area of logistics facilities in Castile-La Mancha is very low, as it is in other regions near Madrid (Castile and Leon, Extremadura) (see Alamá-Sabater et al, 2011 and 2012).

${ }^{10}$ The detailed explanations for the construction of the logistics indices used in the regression analysis are provided in Table A.1 (Appendix).

${ }^{11}$ The ranking based on regional logistics nodes constructed by the Plan Estratégico de Infraestructuras y Transporte (Strategic Plan for Infrastructure and Transport) of the Spanish Ministry of Transport is a combination of modal sections with other multipurpose sections covering seven modes of transport: Road, Rail, Port, Airport, Intermodal freight, Intermodal passengers, Urban and metropolitan transport. As we are dealing with freight, the RELOG project only uses and defines the first five. This methodology has been applied to the nodes that are operating on Spanish soil and we have differentiated between the number of modes of transport that are used at each facility (lorry, train, ship or plane).

${ }^{12}$ Functionality could be considered as the services that a logistics node can provide, such as conventional freight transport (1), intermodal transport (2), or conventional and intermodal transport and receipt, storage, preparation and control of freight (3).
} 
of logistics activities in Spain to that provided by average surface area: Andalusia and the Region of Madrid dominate the logistics scene. However, we must also highlight the importance of regions on the Mediterranean coast (Valencia and Catalonia), where the largest Spanish ports are located; and the importance of the regions neighbouring France (Basque Country and Catalonia). Catalonia, with the Port of Barcelona as well as one of the main routes to France, namely Portbou, has these two key advantages.

The distribution of logistics infrastructure across the various Spanish regions follows not only an economic pattern, but also a geographical one. The Mediterranean, with the important ports of Valencia and Barcelona, is well represented in terms of logistics infrastructure, but the Region of Madrid (organised as the Spanish node), Aragon (with Zaragoza and the roads that connect Madrid to France, the Basque Country and Catalonia) and finally Andalusia (a key region between Spain and North Africa) lead the way in logistics performance in Spain.

Finally, it is worth mentioning that Spanish facilities, due to their strategic location, cater not only for interregional and interregional-international trade flows, but also for transit trade flows. Indeed, the geography of the Mediterranean Sea offers the right conditions for the emergence of transhipment terminals and European gateways are often used as intermediary locations (Rodrigue and Notteboom, 2010). In the particular case of trade flows between North African countries and the United Kingdom, Spain could become a transit hub. Notteboom (2012) states that the North-South and diagonal trade lanes (e.g. North Europe-West Africa and North Europe-South America) are largely connected to the main beltway via transhipment hubs such as Algeciras. Container flows between Asia and the east coast of South America, as well as between Asia and West and South Africa are typically being interlined in transhipment hubs such as Algeciras and Valencia. ${ }^{13}$ Nonetheless, the dependency of container flows on the Suez route is not guaranteed in the long term. In this context, existing transport infrastructure, together with the need to update and modernise facilities, might be cited among the factors that play a fundamental role for regions attempting to attract this type of trade flows (Capineri and Randelli, 2007).

\section{METHODOLOGY, DATA AND VARIABLES}

In order to address the relative impact of logistics on trade, a gravity equation is estimated (Tinbergen, 1962; Linnemann, 1966; Anderson, 1979; Bergstrand, 1985 and 1989; Deardorff, 1995), which we augment to include logistics variables. Tinbergen (1962) was the first to use a gravity equation to explain the determinants of trade flows. Also in the 1960s, Linnemann (1966) provided a Walrasian theoretical justification for this methodology, while Anderson (1979) contributed a theoretical justification using product differentiation. Recent developments concerning theoretical developments as well as estimation methods have been summarised in Head and Mayer (2014).

\footnotetext{
${ }^{13}$ Note that, due to lack of data, the gravity approach does not take into consideration the transhipment traffic in the estimations. Although this could alter the obtained results, it could be argued that the importance of a particular port is defined by its turnover size, independently of the activity of the port.
} 
According to the general gravity model of trade, the volume of aggregate exports between pairs of regions and/or regions and countries, $\mathrm{X}_{\mathrm{ij}}$, depends on the capabilities of exporter $i$ and the characteristics of destination market $j$, and on a number of bilateral factors that may facilitate or deter trade, as indicated in equation (1):

$$
X_{i j}=G S_{i} M_{j} A_{i j}
$$

where $G$ is the gravitational constant, $S_{i}$ is a factor representing the "capabilities" of exporter $i$ as a supplier to all markets and $M_{j}$ indicates all the characteristics of the destination market $j$ that promote imports from all origins, $A_{i j}$ measures bilateral accessibility of $j$ to exporter $i$ regions (countries) and its main component is trade costs.

Traditionally, gravity equations involved using GDPs (as well as other countryspecific factors) as proxies for $\mathrm{S}$ and $\mathrm{M}$, but a more recent practice is to use -in a cross-section estimation- fixed effects instead of these terms (Head and Mayer, 2014). As equation (1) is not linear in parameters, in most cases estimates of the gravity model are based on a log-linear transformation of different versions of equation (1). The linear version is given by the following expression:

$$
\ln X_{i j}=\ln G+\beta \ln S_{i}+\gamma \ln M_{j}+\sum_{k} \delta_{k} A_{i j}+\varepsilon_{i j}(2)
$$

where In denotes variables in natural logarithms and $\sum_{k} \delta_{k} A_{i j}$ represents bilateral variables that facilitate or hinder trade. Some of them are specified as binary variables. The natural logarithm of geographical distance has traditionally been included as a proxy for transportation costs and hence a negative effect of this variable on trade is expected. Gravity models normally include binary dummy variables such as whether or not the trading partners share the same language or have a common border, as well as variables for Free Trade Agreements (FTA), in order to assess the effects of regional integration. That is, these binary variables take a value of one when a given condition is fulfilled (for example, sharing official language, having a common border or belonging to the same FTA) and zero otherwise. The coefficients of most of these variables apart from distance- that affect international trade $\left(\delta_{k}\right)$ are expected to be positive. In addition, according to Anderson and van Wincoop (2003) a theoretically grounded gravity model of trade should also include proxies for trade costs relative to the rest of the world. The so-called multilateral resistance terms have usually been incorporated into the empirical gravity model using exporter and importer fixed effects or bilateral fixed (or random) effects in panel data applications.

This study includes, in addition to distance, other variables that also affect transport costs, namely, logistics and transport infrastructure variables, in order to assess their impact on trade flows. As proxies for these variables, we use the constructed logistics and transport infrastructure indices for the Spanish regions as well as the logistics performance index (LPI) constructed by the World Bank for the destination countries. 
Considering the time dimension over the period 2003-2007, together with the abovementioned indicators to measure the level of logistics performance, the augmented gravity model is specified as shown in equation (3):

$\ln X_{i j t}=\gamma_{0}+\beta_{1} \ln \mathrm{Y}_{i j t}+$

$\beta_{2} \ln D_{i j}+\beta_{3}$ Lang $_{j}+\beta_{4}$ Din $_{i j}+\beta_{5}$ Coast $_{i}+\beta_{6}$ FTA $_{j t}+\beta_{7} B_{i j}+\beta_{8}$ Infr $_{i t}+\beta_{9} L P I_{i}+\beta_{10} L P I_{j}+\tau_{t}+\delta_{i j}+$ sijt (3)

where $\ln X_{i j t}$ denotes exports from a Spanish region $i$ to an importing country (region) $j$ in year $t$; $\ln Y_{i j t}$ is the logarithm of the product of GDP for exporter $i$ and importer $j$ in year $t^{14} D_{i j}$ denotes distance. $L P I_{i}$ is an index that measures the level of logistics performance in each region in Spain, which has been calculated using information on the number of logistics facilities and the number of square kilometres of logistics zones (logistics hardware), the number of services they provide and the modes of transport available at each one (logistics software). Infrit is a land infrastructure index, which measures the level of development of land transport infrastructure as the average kilometres of road and rail in each Spanish region, while $L P l_{j}$ measures the logistics performance of the importing countries using the LPI of the World Bank. Lang;, $\operatorname{Din}_{i j}$, Coast ${ }_{i}, F T A_{j t}$ and $B_{i j}$ are dummy variables that take the value of one when i and $\mathrm{j}$ share an official language; when origin and destination are located in the same country, that is, Spain $\left(\operatorname{Din}_{i j}\right)$; when $i$ is a coastal region (Coast $\left.t_{i}\right)$; when there is a FTA in force between the trading partners $\left(F T A_{j t}\right)$; or when $i$ shares a border with Portugal (BP) or with France (BF). We control for unobserved heterogeneity by using bilateral random effects $\left(\delta_{i j}\right)$ and time fixed effects $\left(\tau_{t}\right)$. Alternatively, we also run estimations using a Mundlak approach, which consist of adding the averages of the time variant variables as regressors to control for unobserved heterogeneity that could be correlated with the time invariant part of the error term and allow us to estimate the effect of the time invariant variables, namely logistics factors. Overall, most of the estimated coefficients are very similar using both methods.

Another issue that we address is that the relationship between trade volumes and logistics infrastructure could be bidirectional. For instance, public and private investments tend to foster economic activity and trade. ${ }^{15}$ In this case, infrastructure causes trade. At the same time, regions that trade intensively will see more investment in facilities, provided by the state or by private investors, which usually react to profitable opportunities. In order to take into account the direction of the causality in our regressions, we consider two instrumental variable estimation methods. First, a Hausman-Taylor approach, an extension of the abovementioned Mundlak approach, which consists of using the averages of the time variant exogenous variables as instruments for the time invariant endogenous variables. Second, an instrumental variables approach

\footnotetext{
${ }^{14}$ Note that in the Tables of results only the coefficient for the size of the market as a whole (total income) is used. The reason is that in preliminary estimations a test of equality of the coefficient of yi and yj could not be rejected.

${ }^{15}$ See Lakshmanan (2011) for an overview of the analytical approaches that estimate the nature and magnitude of the economic consequences of transport infrastructure investments, and Huang (1996) for an application that studies the effect of a change in transportation prices on the regional economy. These papers show that a specific transportation investment can have significant impacts on regional development.
} 
with external excluded instruments in which we use the number of tonnes transported in past years as an instrument for logistics facilities. In our specification, we will also introduce other economic variables as regressors, namely regional capital stock $\left(K_{i}\right)$ and capital stock in information and communication technologies (Kicti) to establish whether they also promote trade. ${ }^{16}$ To avoid endogeneity bias we will introduce these variables with lags, since they are available for several years.

The data and variables used in this research come from different statistical sources, which are listed in Appendix A (Table A.1). Table 2 presents the summary statistics of the variables used in the empirical analysis.

It is important to note that whereas we have time variability for most variables used in the analysis, namely exports, income, infrastructure, and tonnes transported, the logistics regional and international indices are only available for 2007.

Table 2. Trade and logistics in Spain. DescriPtive Statistics

\begin{tabular}{|c|c|c|c|c|c|c|}
\hline & $\begin{array}{l}\text { variables } \\
\text { short } \\
\text { names }\end{array}$ & Obs & Mean & $\begin{array}{l}\text { Std. } \\
\text { Dev. }\end{array}$ & Min & Max \\
\hline (1) Log of bilateral exports & $\ln X_{i j t}$ & 5041 & 2.02 & 3.6 & -14.03 & 11.16 \\
\hline (2) Log of total income & $\ln Y_{i j t}$ & 5720 & 22.54 & 1.94 & 16.32 & 28.94 \\
\hline (3) Log of distance & $\ln D_{i j}$ & 6762 & 7.81 & 1.32 & 3.83 & 9.9 \\
\hline (4) Common language & Lang $_{j}$ & 6864 & 0.34 & 0.47 & 0 & 1 \\
\hline (5) Border with France & $\mathrm{BF}_{\mathrm{ij}}$ & 6864 & 0.22 & 0.41 & 0 & 1 \\
\hline (6) Border with Portugal & $\mathrm{Bp}_{\mathrm{ij}}$ & 6864 & 0.22 & 0.41 & 0 & 1 \\
\hline (7) Coastal region & Coast $_{\mathrm{i}}$ & 6864 & 0.62 & 0.49 & 0 & 1 \\
\hline (8) Intraregional dummy variable & $\operatorname{Din}_{i j}$ & 6864 & 0.25 & 0.43 & 0 & 1 \\
\hline (9) Free Trade Agreement & $\mathrm{FTA}_{\mathrm{ij}}$ & 6864 & 0.15 & 0.36 & 0 & 1 \\
\hline $\begin{array}{l}\text { (10) Number of facilities per } \\
\text { region }\end{array}$ & $\mathrm{NFac}_{\mathrm{i}}$ & 6864 & 15.29 & 13.29 & 1 (Ceuta) & $\begin{array}{l}55 \\
\text { (Andalusia) }\end{array}$ \\
\hline $\begin{array}{l}\text { (11) Log of regional logistics } \\
\text { surface area }\end{array}$ & $\mathrm{MSq}_{\mathrm{i}}$ & 6864 & 15.78 & 1.42 & $\begin{array}{l}13.143 \\
\text { (Extremadura) }\end{array}$ & $\begin{array}{l}17.898 \\
\text { (Andalusia) }\end{array}$ \\
\hline $\begin{array}{l}\text { (12) Capital stock in public } \\
\text { infrastructure }\end{array}$ & $\ln K_{i}$ & 6864 & 17.62 & 1.17 & $\begin{array}{l}14.57779 \\
\text { (Rioja) }\end{array}$ & $\begin{array}{l}19.541 \\
\text { (Madrid) }\end{array}$ \\
\hline $\begin{array}{l}\text { (13) Quality (Capital stock in } \\
\text { information technology) }\end{array}$ & InKict $_{i}$ & 6864 & 14.07 & 1.31 & 11.493 (Rioja) & $\begin{array}{l}17.028 \\
\text { (Andalusia) }\end{array}$ \\
\hline \multicolumn{7}{|l|}{ Standardised variables: } \\
\hline $\begin{array}{l}\text { (14) Regional logistics } \\
\text { performance index }\end{array}$ & $\mathrm{LPI}_{\mathrm{i}}$ & 6864 & 0 & 1 & -1.364 (Rioja) & $\begin{array}{l}2.975 \\
\text { (Andalusia) }\end{array}$ \\
\hline $\begin{array}{l}\text { (15) Regional land infrastructure } \\
\text { index }\end{array}$ & $\operatorname{lnfr}_{\text {it }}$ & 6864 & 0 & 1 & $\begin{array}{l}-3.392 \\
\text { (Melilla) }\end{array}$ & $\begin{array}{l}0.731 \\
\text { (Castilla- } \\
\text { León) }\end{array}$ \\
\hline $\begin{array}{l}\text { (16) Destination country logistics } \\
\text { performance index }\end{array}$ & $\mathrm{LPI}_{\mathrm{j}}$ & 6864 & 0 & 1 & $\begin{array}{l}2.559 \\
\text { (Algeria) }\end{array}$ & $\begin{array}{l}1.578405 \\
\text { (Singapore) }\end{array}$ \\
\hline
\end{tabular}

Source: Authors' elaboration.

\footnotetext{
${ }^{16}$ We are very grateful to an anonymous referee for this suggestion.
} 


\section{EMPIRICAL ANALYSIS}

\subsection{MAIN RESULTS}

Equation (3) is estimated for bilateral exports from 19 Spanish regions to 64 destinations (45 countries and 19 Spanish regions) ${ }^{17}$ with data over the period 2003 to 2007. Although regional and destination logistics variables are currently available for a single period (2007), having additional years of data for the rest of variables enables us to tackle the issues of multilateral resistance and inverse causality between trade and logistics and to estimate the model using panel data techniques. Table 3 presents the results from estimating different versions of equation (3). The first column in Table 3 displays the results obtained from estimating the baseline model using a Mundlak approach with bilateral random effects and time fixed effects (REM).

The results obtained show that our target variable, the regional $\mathrm{LPI}$, is positively correlated with trade. In addition, the LPI of importing countries and the land infrastructure index for Spanish regions also show positive and statistically significant coefficients and have, therefore, a positive relation with exports. A one-standard deviation improvement in the logistics of the exporting region, which implies rising from the 25th to the 75th percentile of the distribution (see Table A.3 in the Appendix), is associated to a $35 \%$ increase in exports. These results suggest that logistics performance is decisive for the exporting regions. The effect of improving regional land infrastructure on exports is also positive and significant, although slightly lower than the effect of improving logistics.

Results also show that an improvement in logistics at destination has a positive and significant correlation with regional exports and this result is in accordance with results using trade among nations. The second column includes capital stock at the regional level. The advantage of this variable is that it has time variability, which means we are able to use lagged values to avoid reversecausality issues. The results indicate that an increase in capital stock has a positive and significant effect on regional exports. In particular, a 10\% increase in capital stock increases regional exports by almost $4 \%$.

Another relevant issue relates to the quality of logistics infrastructure across Spanish regions. At the national level, some indicators are available (from the World Bank or the World Economic Forum) that could be used as proxies for quality factors, namely time needed to handle freight, punctuality, customs clearance times, quality and ease of paperwork, etc. Unfortunately, similar indicators are not available for Spanish regions. We use instead, as a measure of logistics quality, the capital stock in information technology by region. Column 3 in Table $3^{18}$ presents the estimation results, which provide evidence that greater capital stocks in information technology are associated with higher regional exports.

\footnotetext{
${ }^{17}$ Table A.2 in the Appendix lists the countries and regions included in the analysis.

${ }^{18}$ Note that the correlation between the regional logistics index and capital stock in public infrastructure is $82 \%$, while the correlation between the regional logistics index and capital stock in information technology is $65 \%$. Therefore, to avoid multicollinearity problems the regional logistics index was not included in the estimated equations (columns 2 and 3, Table 3).
} 
Concerning the other control variables in equation (3), the variable income has a positive and significant coefficient. The "economic mass" of trading partners has a coefficient close to one, as theory predicts (Bergstrand, 1985). The coefficient of distance displays the expected negative sign, is statistically significant and higher than one in absolute terms. The two additional variables are included as extra factors that facilitate trade (sharing a border with Portugal, $\mathrm{BP}$, and with France, BF) are negative and positive signed, respectively, although the variable border with Portugal is not statistically significant in the baseline regression. According to the results in column 1 of Table 3, Spanish regions neighbouring France export 169\% more than other regions. Spain also trades more $(174 \%)$ with countries where Spanish is the official language. The coefficient of the variable coastal region is in most cases not statistically significant once we incorporate the logistics and land transport infrastructure variables into the model. The results obtained also show that the variable FTA is positive and significant, indicating that Spanish regions export around 30\% more to countries that have signed the same FTA.

It is worth highlighting that according to the intra-regional variable (which takes a value of one for exchanges between Spanish regions), and considering all the other variables as constant, trade flows between two Spanish regions is 26 times greater than trade between a Spanish region and abroad. This result confirms the existence of a border effect in the case of Spain (Gil-Pareja et al, 2005; Requena and Llano, 2010). This border effect (column 1 of Table 3 ) is slightly higher than in the estimations of McCallum (1995), which showed that Canadian cross-provincial trade was 22 times larger than cross-border trade with states in the United States. The use of bilateral trade between Spanish regions and countries, without using regional data for the destinations, could lead to an upwards bias in the estimated border effect. Indeed, using a gravity framework, Llano-Verduras et al (2011) analysed the importance of geographical aggregation for the border effect and obtained a sizable border effect for Spain when intra-national partners are aggregated, while the border effect decreased substantially once intra-national destinations were considered.

Column 4 presents the results obtained using an alternative method to control for multilateral resistance in the destination markets that consists of replacing the destination variables with destination fixed effects. The results concerning the regional logistics and infrastructure variables remain almost unchanged and the border effect is considerably reduced.

Finally, in column 5 of Table 3 the model is estimated using a Hausman-Taylor approach in which the variables regional logistics and internal trade are considered as endogenous. According to this method, the averages of the time varying variables (income, infrastructure and capital stock in ITC) are taken as instruments for the time invariant variables considered as endogenous (internal distance and infrastructure index). The choice of these instruments is justified since the variables are correlated with the endogenous variables (see R2 of the corresponding first step regressions at the bottom of Table 3) and also pass the corresponding test of overidentifying restrictions (see results at the bottom of Table 3). 
TABle 3. MAin Estimation Results

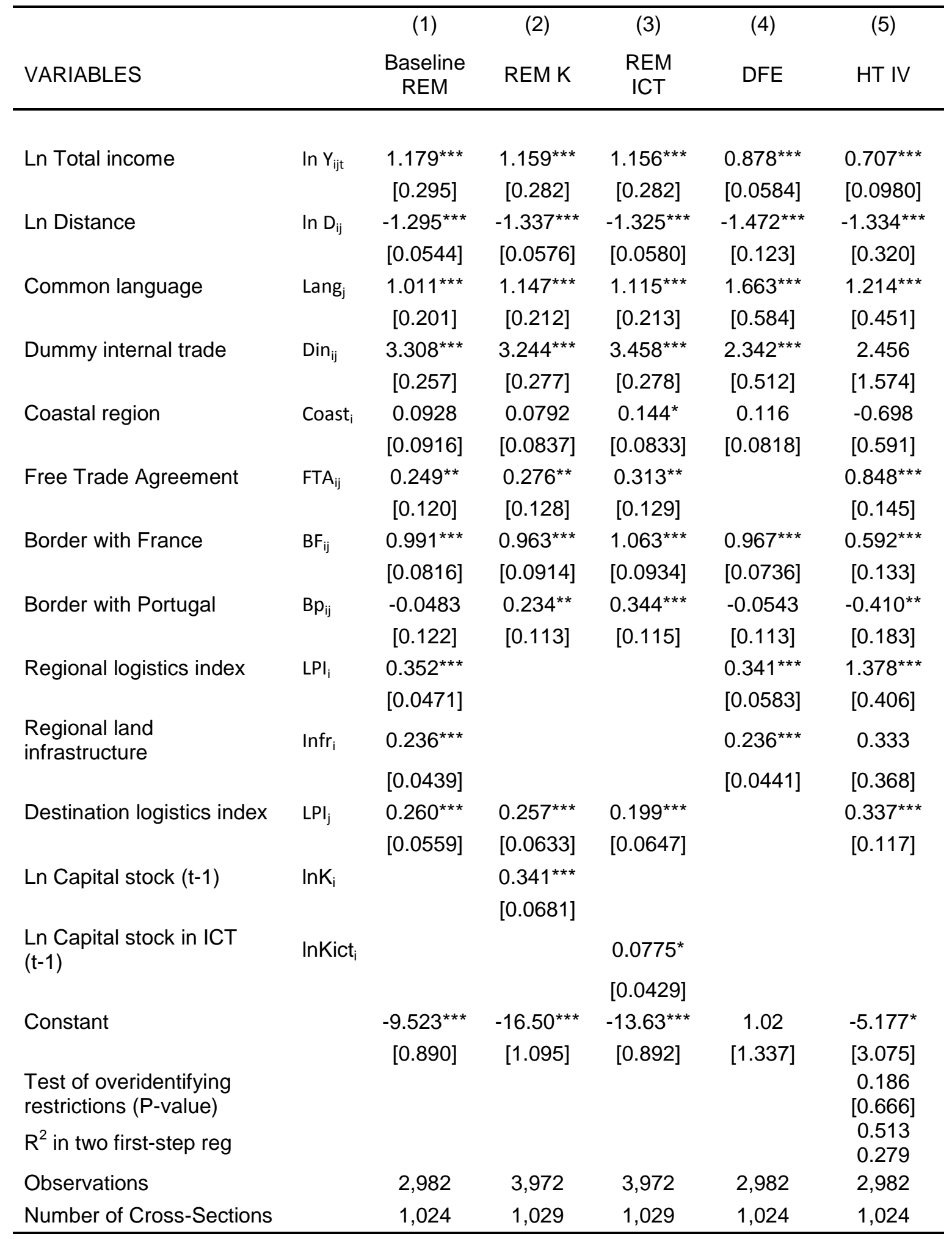

Note: Robust standard errors in brackets. ${ }^{* *},{ }^{* *}$, ${ }^{*}$ indicate significance at the $1 \%, 5 \%$ and $10 \%$ levels, respectively. REM denotes random effects-Mundlak approach, DFE denotes destination fixed effects and HT IV denotes Hausman-Taylor instrumental variables.

The coefficient estimated for the logistics index is much higher in magnitude 
that the one obtained in columns (1) to (4) indicating that controlling for endogeneity increases the positive effect of logistics on export flows. As a robustness check, we also try alternative methods using the amount of tonnes transported in each region in past years as external instrument, and the results were very similar. ${ }^{19}$

\subsection{SENSITIVITY ANALYSIS}

A number of robustness checks are presented in this section. First, we experiment with single dimensions of our logistics index in the gravity model. In particular, Table 4 presents the results of disentangling the effect of two of the variables used to proxy logistics hardware, namely number and area of logistics facilities in each region. Column 1 in Table 4 shows the results for number of facilities and indicates that adding one facility increases exports by around $2 \%$. Furthermore, column 2 shows a positive and significant effect indicating that when the surface dedicated to logistics increases by $10 \%$ in a region, its exports increase by $1.4 \%$.

Second, we consider the importance of maritime infrastructures for trade and the role of ports in enhancing international competitiveness as a separate issue. The main reasons for doing so are threefold. First, maritime trade represents between 55 and $80 \%$ of the value of total goods exported from Spanish regions to the 45 destination countries in the sample. Second, ports usually connect international and interregional-intermodal trade flows and third, we notice that a number of the logistics nodes considered in this study are not significant for freight. ${ }^{20}$ Hence, although port facilities were included in the computation of the logistics index used above, we claim that they deserve a separate analysis.

To proxy for port facilities, three variables are chosen. First, we use information about sea traffic from the Annual Accounts of the 28 Spanish Port Authorities over the years 2003 to 2007 (as in González and Trujillo, 2008; Núñez-Sánchez et al, 2011; Núñez-Sánchez and Coto-Millán, 2012; and Márquez-Ramos and Aparisi-Caudeli, 2013). This variable is included in column 3 of Table 4 and its estimated coefficient is found to be positive and statistically significant, indicating that regions that have ports with more sea traffic export more than others. Second, we use information on investment in new technologies (computer and information processing equipment) provided by the 28 Spanish ports to proxy for the quality of port facilities ${ }^{21}$ in a broad sense, as the facilities that invest more in information technology are expected to offer better port services than others.

\footnotetext{
${ }^{19}$ Results are available from the authors on request.

${ }^{20}$ Indeed, EU transport statistics show that only Madrid-Barajas and Barcelona airports feature in the top $40 \mathrm{EU}$ airports for cargo. A list is available at Eurostat.

(http://epp.eurostat.ec.europa.eu/statistics_explained/index.php/Air_transport_statistics).

21 Our main analysis also included a proxy for quality at regional level which might be considered to represent a narrow definition and that was a component of the logistics index. However, to use a proxy for quality of logistics facilities in a broad sense, we rely on comparable information provided by port facilities.
} 
Next, we create standardised values of the interaction between an indicator measuring the relative importance of port facilities at a regional level ${ }^{22}$ and the variable investments in information technology (portitic). This variable is added in column 4 of Table 4 , and its coefficient is positive but is not statistically significant.

Finally, we use the ratio of net turnover over staff costs as a labor productivity measure on the port site, which is included in column 5 of Table 4. This variable is also positively correlated with regional exports. We also try alternative specifications with lagged values of the port facility variables and the results remain unchanged.

Table 4. Trade and logistics in Spain. Sensitivity analysis

\begin{tabular}{|c|c|c|c|c|c|c|}
\hline \multirow[b]{2}{*}{ VARIABLES } & & (1) & (2) & (3) & (4) & (5) \\
\hline & & REM & REM & $\begin{array}{l}\text { Portinf } \\
\text { REM }\end{array}$ & $\begin{array}{l}\text { Port_ITC } \\
\text { REM }\end{array}$ & $\begin{array}{l}\text { LabProd } \\
\text { REM }\end{array}$ \\
\hline \multirow[t]{2}{*}{ Ln Total income } & $\ln Y_{\mathrm{ijt}}$ & $1.529^{\star \star *}$ & $1.529^{\star \star \star}$ & $1.528^{* \star *}$ & $1.532^{\star * \star}$ & $1.129^{* \star *}$ \\
\hline & & [0.243] & [0.243] & {$[0.244]$} & {$[0.244]$} & {$[0.294]$} \\
\hline \multirow[t]{2}{*}{ Ln Distance } & $\ln D_{i j}$ & $-1.360^{* * *}$ & $-1.363^{\star \star *}$ & $-1.358^{\star \star *}$ & $-1.347^{* \star *}$ & $-1.349^{\star \star \star}$ \\
\hline & & {$[0.0707]$} & {$[0.0710]$} & [0.0708] & [0.0711] & {$[0.0661]$} \\
\hline \multirow[t]{2}{*}{ Common language } & Lang $_{j}$ & $1.087^{\star \star \star}$ & $1.087^{* \star \star}$ & $1.076^{\star \star \star}$ & $1.069^{\star \star \star}$ & $1.045^{\star \star \star}$ \\
\hline & & {$[0.210]$} & {$[0.211]$} & {$[0.212]$} & {$[0.212]$} & {$[0.206]$} \\
\hline \multirow[t]{2}{*}{ Coastal region } & Coast $_{i}$ & 0.0668 & -0.0102 & -0.165 & 0.0554 & $-0.286^{*}$ \\
\hline & & [0.105] & {$[0.107]$} & {$[0.156]$} & [0.124] & [0.159] \\
\hline \multirow[t]{2}{*}{ Free Trade Agreement } & $\mathrm{FTA}_{\mathrm{ij}}$ & $0.238^{*}$ & $0.238^{*}$ & $0.247^{\star}$ & $0.262^{* *}$ & 0.197 \\
\hline & & {$[0.132]$} & {$[0.133]$} & {$[0.133]$} & {$[0.133]$} & {$[0.127]$} \\
\hline \multirow[t]{2}{*}{ Border with France } & $\mathrm{BF}_{\mathrm{ij}}$ & $1.290^{* \star *}$ & $1.313^{\star \star \star}$ & $1.241^{\star \star \star}$ & $1.338^{\star \star \star}$ & $1.236^{\star \star *}$ \\
\hline & & {$[0.105]$} & {$[0.108]$} & {$[0.115]$} & {$[0.108]$} & {$[0.103]$} \\
\hline \multirow[t]{2}{*}{ Border with Portugal } & $\mathrm{Bp}_{\mathrm{ij}}$ & 0.204 & $0.518^{\star \star \star}$ & 0.258 & $0.363^{\star \star \star}$ & $-0.420^{* *}$ \\
\hline & & {$[0.137]$} & {$[0.136]$} & {$[0.158]$} & {$[0.140]$} & {$[0.165]$} \\
\hline \multirow[t]{2}{*}{ Destination logistics index } & $\mathrm{LPI}_{\mathrm{j}}$ & $0.205^{\star \star *}$ & $0.200^{\star \star *}$ & $0.187^{\star \star \star}$ & $0.146^{* *}$ & $0.244^{* * *}$ \\
\hline & & {$[0.0631]$} & [0.0619] & [0.0629] & [0.0635] & {$[0.0567]$} \\
\hline \multirow[t]{2}{*}{ Number of logistics facilities } & $\mathrm{NFac}_{i}$ & $0.0191^{* * *}$ & & & & \\
\hline & & {$[0.00356]$} & & & & \\
\hline \multirow[t]{2}{*}{$\begin{array}{l}\text { Ln Surface area of logistics } \\
\text { facilities }\end{array}$} & $\mathrm{MSq}_{\mathrm{i}}$ & & $0.145^{\star \star \star}$ & & & \\
\hline & & & {$[0.0463]$} & & & \\
\hline \multirow[t]{2}{*}{ Regional port facilities } & Port $_{i}$ & & & $0.201^{\star \star \star}$ & & \\
\hline & & & & [0.0751] & & \\
\hline \multirow[t]{2}{*}{ ITC interaction (Portitic) } & Portitic $_{i}$ & & & & 0.0668 & \\
\hline & & & & & [0.0438] & \\
\hline \multirow[t]{2}{*}{$\begin{array}{l}\text { Regional port labor } \\
\text { productivity }\end{array}$} & Prod $_{i}$ & & & & & $0.443^{* \star *}$ \\
\hline & & & & & & [0.0739] \\
\hline
\end{tabular}

$22 \%$ of sea traffic over total sea traffic in Spain in 2003-2007. 


\begin{tabular}{lcccccc} 
Regional land infrastructure & Infr $_{\mathrm{i}}$ & & & & & $0.332^{* * *}$ \\
& & & & & & {$[0.0531]$} \\
Constant term & -4.672 & $-6.914^{*}$ & -5.145 & $-6.287^{*}$ & -5.949 \\
& {$[3.622]$} & {$[3.615]$} & {$[3.643]$} & {$[3.637]$} & {$[4.092]$} \\
Observations & 3,633 & 3,633 & 3,633 & 3,633 & 2,188 \\
Number of Cross-sections & 768 & 768 & 768 & 768 & 758 \\
\hline
\end{tabular}

Note: Robust standard errors in brackets. ${ }^{* * *},{ }^{* *},{ }^{*}$ indicate significance at the $1 \%, 5 \%$ and $10 \%$ levels, respectively. REM denotes random effects-Mundlak approach.

\section{CONCLUSIONS}

The latest developments in logistics and transport infrastructure are crucial when it comes to fostering trade and, in turn, the competitiveness of national products in international markets. This paper analyses the effect of logistics and infrastructure on international and interregional trade flows in Spain. A better understanding of this effect could be used as a guide for possible transport policy actions at a European level.

With this purpose in mind, we estimate a gravity model augmented with logistics and infrastructure variables for Spanish domestic and foreign trade. The main results of this study confirm the relative importance of the logistics factors analysed when compared to other variables that are traditionally considered in standard gravity models of trade.

Apart from the expected results of the effect of income and distance on trade flows, the geographical location of Spain is important when explaining trade with neighbouring countries, particularly France. The coefficient obtained for the common border in the regressions indicates that Spanish regions neighbouring France export more, taking into account distance and the rest of the control variables. The existence of a border effect is confirmed by comparing trade between Spanish regions and exports to third countries. Similarly, the estimation of the effect of the free trade agreement variable indicates that Spanish regions export more to destinations within the same FTA. Finally, this study shows that an improvement in the logistics sector in Spanish regions would have a positive effect on Spanish exports. In the case of logistics facilities, their presence and size (number and surface area) in Spanish regions also has a positive impact on trade operations. Nevertheless, further research with more detailed information on the specific characteristics of the facilities (specialisation, degree of intermodality, etc.) as well as regional logistics performance measures in trading partners will be aimed at assessing the effects of an integrated Spanish network of logistics facilities on trade.

This research has important policy implications in a country characterised by an extensive network of roads, railways, rapid transit, air routes and ports. Indeed, an efficient and effective transport network might be constructed in different ways, such as completing missing links, alleviating bottlenecks or by using more efficient services in multimodal combinations. Logistics facilities play a fundamental role in accomplishing these goals.

Nonetheless, disadvantages such as those found in the longer-distance European freight markets for transit flows across the Spain-France border might 
be tackled only by means of coordinated actions targeting logistics at supranational level. In addition, the position of Spanish maritime ports as transshipment hubs faces competition today in the Mediterranean area from newly built or completely redeveloped ports (such as Tangiers in Morocco, mainly managed by the Maersk group and the port of Pireus in Greece, under Chinese management), making this line of research crucial for European Union policy makers.

International organisations, such as the World Bank, propose the use of new variables to classify countries according to the level of their logistics facilities. This study shows the importance of logistics performance in regard to international competitiveness also at the regional level. As further research, we suggest the construction of a logistics index at the regional level for a crosssection of countries and for several years. In this way, more in-depth and reliable information will be made available to further investigate the relationship between regional logistics and trade. 
Alamá-Sabater, L., Márquez-Ramos, L., Suárez-Burguet, C. and NavarroAzorín, J.M. (2012): "Interregional Trade and Transport Connectivity. An Analysis of Spatial Dependence". Working paper 2012/20, Universitat Jaume I, Castellón.

Alamá-Sabater, L., Márquez-Ramos, L. and Suárez-Burguet, C. (2011): "La relación entre el comercio interregional y la conectividad del transporte en España. Un análisis de dependencia espacial". Revista de Economía y Estadística, vol. XLIX (1), 7-32.

Alamá-Sabater, L., Márquez-Ramos, L. and Suárez-Burguet (2013): "Trade and transport connectivity: a spatial approach". Applied Economics, Taylor \& Francis Journals, vol. 45(18), 2563-2566.

Anderson, James E. (1979): "A Theoretical Foundation for the Gravity Equation" American Economic Review, Vol. 69 (1), 106-116.

Anderson, J. E. and Van Wincoop, E. (2003): "Gravity with gravitas: A solution to the border puzzle", American Economic Review, 93(1), 170-192.

Bergstrand, J. H. (1985): "The gravity equation in international trade: Some micro-economic foundations and empirical evidence", The Review of Economics and Statistics, 67(3), 474-481.

Bergstrand, J. H. (1989): "The generalized gravity equation, monopolistic competition, and the factor-proportions theory in international trade", The Review of Economics and Statistics, 71(1), 143-153.

Bernhofen, D. M., El-Sahli, Z. and Kneller, R. (2013), "Estimating the effects of the container revolution on international trade", paper presented in the $X$ Jornadas sobre Integración Económica 2013, 28-29 November, Universitat Jaume I.

Capineri, C. and Randelli, F. (2007): "Freight transportation flows: New trade regions and trade routes", European Journal of Transport and Infrastructure Research 7(2), 93-112.

Clark, X., D. Dollar and A. Micco (2004): "Port efficiency, maritime transport costs, and bilateral trade". Journal of Development Economics, 75(2), 417-450.

Coca-Castaño, P., Márquez-Ramos, L. and Martínez-Zarzoso, I. (2005), "Infraestructuras, costos de transporte y flujos de comercio", Revista de Análisis Económico, 20(1), 3-22.

Deardorff, A. V. (1995): "Determinants of bilateral trade: Does gravity work in a Neo-classical word?", NBER Working Paper 5377.

ECORYS Nederland BV (2006): "Study on Strategic Evaluation on Transport Investment Priorities under Structural and Cohesion funds for the Programming Period 2007-2013: Country Report Spain". Rotterdam.

European Commission (2011): "Connecting Europe: The new EU core transport network", MEMO/11/706. Available online:

http://europa.eu/rapid/press-release_MEMO-11-706_en.htm

Fundación BBVA-IVIE (2007): Capital stock in Spain and its distribution by territories (1964-2011). Annex (in Spanish). Data by Regions. http://www.ivie.es/en/banco/stock/banco2.php (accessed 16 January 2014).

Gil-Pareja, S., Llorca-Vivero, R., Martínez-Serrano, J. A. and Oliver-Alonso, J. (2005): "The Border Effect in Spain", The World Economy, 28(11), 1617-1631. 
González, M. M. and Trujillo, L. (2008): "Reforms and infrastructure efficiency in Spain's container ports", Transportation Research Part A: Policy and Practice, Volume 42 (1), 243-257.

Gutiérrez, J. and Urbano, P. (1996): "Accessibility in the European Union: the impact of the trans-European road network." Journal of Transport Geography, 4 (1), 15-25.

Head, K., and T. Mayer (2014): "Gravity Equations: Workhorse, Toolkit, and Cookbook." Forthcoming in G. Gopinath, E. Helpman and K. Rogoff (ed): Handbook of International Economics, Vol. 4. Amsterdam, Elsevier-North Holland.

Huang, C-H. (1996): Transportation and regional development. Doctoral Dissertation. University of Pennsylvania, 1994. Supervisor: W. Bruce Allen. Transportation Research Part A: Policy and Practice 30 (1), page 82.

INE-Instituto Nacional de Estadística- Spanish Statistics Institute (2011): Boletín Mensual de Estadística: http://www.ine.es.

Jacks, D. S. and Pendakur, K. (2010): "Global Trade and the Maritime Transport Revolution," The Review of Economics and Statistics, MIT Press, 92(4), 745-755.

Lakshmanan, T.R. (2011): "The broader economic consequences of transport infrastructure investments." Journal of Transport Geography, 19, 1-12.

Limão, N. and Venables, A.J. (2001): "Infrastructure, Geographical Disadvantage and Transport Costs". World Bank Economic Review, 15, 451479.

Linnemann, H. (1966): "An Econometric Study of International Trade Flows" Amsterdam: North-Holland Publishing Company.

Llano-Verduras, C., Minondo, A. and Requena-Silvente, F. (2011): "Is the Border Effect an Artefact of Geographical Aggregation?", The World Economy 34(10), 1771-1787.

Márquez-Ramos, L. and Aparisi-Caudeli, J. A. (2013): "The Impact of Management Accounting Systems on International Markets: Theory and Evidence Using the Balanced Scorecard Approach". The Journal of Applied Management Accounting Research 11(2).

Márquez-Ramos, L., Martínez-Zarzoso, I., Pérez-García, E. and Gordon Wilmsmeier, G. (2011): "Special Issue on Latin-American Research" Maritime Networks, Services Structure and Maritime Trade, Networks and Spatial Economics, 11(3), 555-576.

Márquez-Ramos, L., Martínez-Zarzoso, I. and Suárez-Burguet, C. (2012), "Trade Policy versus Trade Facilitation: An Application Using "Good Old" OLS", Economics: The Open-Access, Open-Assessment E-Journal, 6, Available at: http://dx.doi.org/10.5018/economics-ejournal.ja.2012-11.

Martínez-Zarzoso, I., García-Menéndez, L. and Suárez-Burguet, C. (2003): "Impact of Transport Costs on International Trade: The Case of Spanish Ceramic Exports". Maritime Economics and Logistics, 5(2), 179-198.

Martínez-Zarzoso, I. and Márquez-Ramos, L. (2008), "The Effect of Trade Facilitation on Sectoral Trade", The B.E. Journal of Economic Analysis \& Policy, 8(1), (Topics), Article $42 . \quad$ Available at: http://www.bepress.com/bejeap/vol8/iss1/art42.

McCallum, J. (1995). "National Borders Matter: Canada-U.S. Regional Trade Patterns". American Economic Review 85, 3, 615-23. 
Micco, A. and Serebrisky, T. (2004): "Infrastructure, competition regimes, and air transport costs: cross-country evidence". Policy Research Working Paper Series 3355, World Bank. Washington.

Miles, M. A., E. J. Feulner JR., M. A. O'Grady and A. I. Eiras (2004): Index of Economic Freedom. The Heritage Foundation.

Notteboom, T. E. (2012): "Towards a new intermediate hub region in container shipping? Relay and interlining via the Cape route vs. the Suez route." Journal of Transport Geography, 22, 164-178.

Núñez-Sánchez, R. and Coto-Millán, P. (2012): "The impact of public reforms on the productivity of Spanish ports: A parametric distance function approach". Transport Policy 24, 99-108.

Núñez-Sánchez, R., Jara-Díaz, S., Coto-Millán, P. (2011): "Public regulation and passengers importance in port infrastructure costs". Transportation Research A: Policy and Practice 45 (7), 653-666.

Persson, M. (2012): "From Trade Preferences to Trade Facilitation: Taking Stock of the Issues", Economics: The Open-Access, Open-Assessment EJournal 6, Available at: http://dx.doi.org/10.5018/economics-ejournal.ja.2012-17. Puertos del Estado (Several years): Anuario Estadístico. Ministry of Transport, Madrid.

Puertos del Estado (2014): "Spanish Association for the Promotion of Short Sea Shipping (SSS)" http://www.puertos.es/en/content/spanish-associationpromotion-short-sea-shipping-sss (accessed 17 January 2014).

Requena, F. and Llano, C. (2010): "The border effect in Spain: An industry-level analysis". Empirica, 37(4), 455-476.

Rodrigue, J. P. and Notteboom, T. (2010): "Comparative North American and European gateway logistics: the regionalism of freight distribution." Journal of Transport Geography, 18, 497-507.

Sanchez, R.J., J. Hoffmann, A. Micco, G.V. Pizzolitto, M. Sgut and G. Wilmsmeier (2003): "Port Efficiency and International Trade: Port Efficiency as a Determinant of Maritime Transport Costs". Maritime Economics \& Logistics, 5, 199-218.

Solakivi, T., L. Ojala, J. Töyli, H. Hälinen, H. Lorentz, K. Rantasila and T. Naula (2009): Finland State of Logistics 2009. Report for the Finish Ministry of Transport and Communications 21/2009, Helsinki.

Suárez-Burguet, C. (2012): "Definition of a Spanish Logistics Platforms Network, RELOG" Technical Report, mimeo, Ministry of Transport, Madrid. In http://iei.uji.es/?opcion=grupo\&id=14\&idioma=es

Tinbergen, J. (1962): "Shaping the World Economy" New York: Twentieth Century Fund.

United Nations Development Programme, UNDP (2001): Human Development Report, New York, Oxford University Press.

Wang, J., Mo, H., Wang, F., and Jin, F. (2011): "Exploring the network structure and nodal centrality of China's air transport network: A complex network approach". Journal of Transport Geography 19(4), 712-721.

Wilson, J.S., Mann, C.L. and Otsuki, T. (2005): "Assessing the benefits of trade facilitation: A Global Perspective”, The World Economy 28(6), 841-871.

World Trade Organization (1998): "WTO: a training package: what is trade facilitation?" Available at: 
http://www.wto.org/english/thewto_e/glossary_e/trade_facilitation_e.htm (accessed 7 October 2013).

World Bank (2007 and 2010): Connecting to compete. Trade Logistics in the Global Economy. Washington.

\section{APPENDIX A}

TABLE A.1. VARIABLES AND DATA SOURCES USED

\begin{tabular}{|c|c|c|}
\hline Variable & Description and construction & Source \\
\hline Exports $\left(\mathrm{X}_{\mathrm{ijt}}\right)$ & Bilateral exports in Euros (2003-2007) & $\begin{array}{l}\text { For trade region-region: C-intereg } \\
\text { database on goods trade } \\
\text { http://www.c-intereg.es/ } \\
\text { For trade region-country: } \\
\text { Datacomex } \\
\text { http://datacomex.comercio.es/ }\end{array}$ \\
\hline Regional income & $\begin{array}{l}\text { Nominal income of Spanish } \\
\text { Autonomous Regions (Euros) (2003- } \\
\text { 2007) }\end{array}$ & $\begin{array}{l}\text { Eurostat (2010), } \\
\text { http://epp.eurostat.ec.europa.eu/po } \\
\text { rtal/page/portal/eurostat/home/ }\end{array}$ \\
\hline Regional population & Number of inhabitants (2003-2007) & $\begin{array}{l}\text { Eurostat (2010) } \\
\text { http://epp.eurostat.ec.europa.eu/po } \\
\text { rtal/page/portal/eurostat/home/ }\end{array}$ \\
\hline Country income & GDP (US\$) (2003-2007) & $\begin{array}{l}\text { The World Development Indicators } \\
\text { (World Bank) }\end{array}$ \\
\hline Distance $\left(D_{\mathrm{ij}}\right)$ & Distance between regional capitals $(\mathrm{km})$ & http://www.indo.com/distance/ \\
\hline $\begin{array}{l}\text { Common border }\left(\mathrm{BF}_{\mathrm{ij}} \text { or }\right. \\
\left.\mathrm{Bp}_{\mathrm{ij}}\right)\end{array}$ & $\begin{array}{l}\text { Dummy variable that takes a value of } 1 \\
\text { when the origin region neighbours } \\
\text { France (BF) or Portugal (BP) }\end{array}$ & Authors' elaboration \\
\hline $\begin{array}{l}\text { Common language } \\
\text { (Lang })\end{array}$ & $\begin{array}{l}\text { Dummy variable that takes a value of } 1 \\
\text { when Spanish is an official language of } \\
\text { the destination country }\end{array}$ & Authors' elaboration \\
\hline Coastal region (Coast ${ }_{\mathrm{i}}$ ) & $\begin{array}{l}\text { Dummy variable that takes a value of } 1 \\
\text { when the origin region is on the coast }\end{array}$ & Authors' elaboration \\
\hline $\begin{array}{l}\text { Intraregional dummy } \\
\text { variable }\left(\operatorname{Din}_{\mathrm{ij}}\right)\end{array}$ & $\begin{array}{l}\text { Dummy variable that takes a value of } 1 \\
\text { when trade occurs between Spanish } \\
\text { regions }\end{array}$ & Authors' elaboration \\
\hline $\begin{array}{l}\text { Free trade agreement } \\
\left(\text { FTA }_{\mathrm{ij}}\right)\end{array}$ & $\begin{array}{l}\text { Dummy variable that takes a value of } 1 \\
\text { when Spain and the destination country } \\
\text { belong to the same trade agreement }\end{array}$ & Authors' elaboration \\
\hline $\begin{array}{l}\text { Regional logistics } \\
\text { performance index ( } \\
\left.\mathrm{LPI}_{\mathrm{i}}\right)\end{array}$ & $\begin{array}{l}\text { Simple standardised mean of the } \\
\text { number of logistics facilities, available } \\
\text { surface area of the facility, the number } \\
\text { of modes of transport and the number of } \\
\text { operations performed in each Spanish } \\
\text { region (2007) }\end{array}$ & $\begin{array}{l}\text { Authors' elaboration based on } \\
\text { information compiled in Suárez- } \\
\text { Burguet (2012) }\end{array}$ \\
\hline $\begin{array}{l}\text { Number of facilities } \\
\text { (component of the } \\
\text { logistics hardware) } \\
\left(\mathrm{NFac}_{\mathrm{i}} \text { ) }\right.\end{array}$ & $\begin{array}{l}\text { Number of facilities by Spanish region } \\
(2007)\end{array}$ & Suárez-Burguet (2012) \\
\hline $\begin{array}{l}\text { Facility surface area } \\
\text { (component of the } \\
\text { logistics hardware) } \\
\left(\mathrm{MSq}_{\mathrm{i}}\right)\end{array}$ & $\begin{array}{l}\text { Surface area devoted to logistics } \\
\text { activities by Spanish region }\left(\mathrm{m}^{2}\right)(2007)\end{array}$ & Suárez-Burguet (2012) \\
\hline
\end{tabular}




\begin{tabular}{|c|c|c|}
\hline $\begin{array}{l}\text { Capital stock in public } \\
\text { infrastructure }\left(\mathrm{K}_{\mathrm{i}}\right)\end{array}$ & $\begin{array}{l}\text { Net capital stock in public infrastructure } \\
\text { by region }\end{array}$ & Fundación BBVA-IVIE (2007) \\
\hline $\begin{array}{l}\text { Quality (narrow } \\
\text { definition) (Kicti) }\end{array}$ & $\begin{array}{l}\text { Net capital stock in information } \\
\text { technology by region }\end{array}$ & Fundación BBVA-IVIE (2007) \\
\hline $\begin{array}{l}\text { Number of logistics } \\
\text { operations by logistics } \\
\text { facility }\end{array}$ & $\begin{array}{l}\text { Variable that takes values between } 1 \\
\text { and } 3 \text { depending on whether the facility } \\
\text { is devoted to conventional transport (1), } \\
\text { intermodal transport (2) or conventional } \\
\text { and intermodal transport and receipt, } \\
\text { storage, preparation and control of } \\
\text { freight (3) (2007) }\end{array}$ & Suárez-Burguet (2012) \\
\hline $\begin{array}{l}\text { Modes of transport by } \\
\text { facility }\end{array}$ & $\begin{array}{l}\text { Variable that takes values between } 1 \\
\text { and } 4 \text { depending on the number of } \\
\text { modes of transport that are used at each } \\
\text { facility (lorry, train, ship, plane) (2007) }\end{array}$ & Suárez-Burguet (2012) \\
\hline $\begin{array}{l}\text { Regional land } \\
\text { infrastructure index } \\
\left(\text { Infr }_{i}\right)\end{array}$ & $\begin{array}{l}\text { Simple standardised mean of the } \mathrm{km} \text { of } \\
\text { road and the } \mathrm{km} \text { of rail in each Spanish } \\
\text { region (2003-2007) }\end{array}$ & $\begin{array}{l}\text { Authors' elaboration based on data } \\
\text { from Eurostat (2010) }\end{array}$ \\
\hline $\begin{array}{l}\text { Destination Logistics } \\
\text { Performance Index ( } \\
\left.\mathrm{LPI}_{\mathrm{j}}\right)\end{array}$ & $\begin{array}{l}\text { Logistics performance in the destination } \\
\text { country. Takes into account six } \\
\text { dimensions: customs processes, quality } \\
\text { of infrastructure, international } \\
\text { dispatches, logistics competence, } \\
\text { tracing and monitoring, and logistics } \\
\text { costs and punctuality (2007) }\end{array}$ & World Bank (2007) \\
\hline $\begin{array}{l}\text { Regional port facilities } \\
\left.\text { (Port }{ }_{i}\right)\end{array}$ & $\begin{array}{l}\text { Standardised values of the relative } \\
\text { importance of port facilities (by region) } \\
\text { Calculated as the percentage of sea } \\
\text { traffic in a region over total traffic in all } \\
\text { Spanish regions (2003-2007) }\end{array}$ & $\begin{array}{l}\text { Márquez-Ramos and Aparisi- } \\
\text { Caudeli (2013) }\end{array}$ \\
\hline $\begin{array}{l}\text { Regional port labor } \\
\text { productivity }\left(\text { Prod }_{i}\right)\end{array}$ & $\begin{array}{l}\text { Standardised values of the value of net } \\
\text { turnover over staff costs in port facilities } \\
(2003-2007)\end{array}$ & $\begin{array}{l}\text { Annual Accounts from Port } \\
\text { Authorities (2003-2007). See Table } \\
1 \text { in Márquez-Ramos and Aparisi- } \\
\text { Caudeli (2013) }\end{array}$ \\
\hline $\begin{array}{l}\text { Portitic }_{i} \text { (Quality: broad } \\
\text { definition) }\end{array}$ & $\begin{array}{l}\text { Standardised values of the interaction } \\
\text { between the relative importance of port } \\
\text { facilities and their corresponding } \\
\text { investment in information technology } \\
(2003-2007)\end{array}$ & $\begin{array}{l}\text { Annual Accounts from Port } \\
\text { Authorities (2003-2007). See } \\
\text { Puertos del Estado (several years), } \\
\text { http://www.puertos.es/ }\end{array}$ \\
\hline Tonnes transported & $\begin{array}{l}\text { Tonnes transported within each region } \\
(2003-2007)\end{array}$ & $\begin{array}{l}\text { Ministerio de Fomento } \\
(2003-2007)\end{array}$ \\
\hline
\end{tabular}


TABLE A.2. LIST OF REGIONS AND COUNTRIES

\begin{tabular}{|l|l|}
\hline Country & Country \\
\hline Germany & Poland \\
\hline Algeria & Portugal \\
\hline Argentina & $\begin{array}{l}\text { United } \\
\text { Kingdom }\end{array}$ \\
\hline Australia & Czech Republic \\
\hline Austria & Singapore \\
\hline Bangladesh & South Africa \\
\hline Belgium & Sweden \\
\hline Brazil & Thailand \\
\hline Canada & Tunisia \\
\hline Chile & Turkey \\
\hline China & Venezuela \\
\hline Colombia & Vietnam \\
\hline South Korea & Region \\
\hline Denmark & Andalusia \\
\hline Egypt & Aragon \\
\hline United States & Asturias \\
\hline Finland & $\begin{array}{l}\text { Balearic } \\
\text { Islands }\end{array}$ \\
\hline France & Canary Islands \\
\hline Greece & Cantabria \\
\hline Hong Kong & Ceuta \\
\hline India & Mancha La \\
\hline Indonesia & $\begin{array}{l}\text { Castile and } \\
\text { Leon }\end{array}$ \\
\hline Ireland & Catalonia \\
\hline Italy & Madrid \\
\hline Japan & Valencia \\
\hline Jordan & Extremadura \\
\hline Lebanon & Galicia \\
\hline Malaysia & Rioja \\
\hline Morocco & Mexico \\
\hline New Zealand & \\
\hline Netherlands & Maran \\
\hline
\end{tabular}


Table A.3. Percentiles by Region (FROM highest to lowest VAlue of the REGIONAL LPI INDEX AND THE LAND INFRASTRUCTURE INDEX)

\begin{tabular}{|c|c|c|}
\hline Region & Regional LPI & Percentile \\
\hline Andalusia & 2.974 & 90 \\
\hline Catalonia & 0.963 & 90 \\
\hline Madrid & 0.763 & 90 \\
\hline Basque Country & 0.722 & 75 \\
\hline Valencia & 0.691 & 75 \\
\hline Castile-La Mancha & 0.605 & 50 \\
\hline Galicia & 0.441 & 50 \\
\hline Aragon & -0.020 & 50 \\
\hline Canary Islands & -0.105 & 50 \\
\hline Cantabria & -0.218 & 50 \\
\hline Murcia & -0.247 & 25 \\
\hline Asturias & -0.441 & 25 \\
\hline Navarra & -0.689 & 25 \\
\hline Castile and Leon & -0.756 & 25 \\
\hline Balearic Islands & -0.774 & 25 \\
\hline Extremadura & -0.798 & 25 \\
\hline Melilla & -1.155 & 10 \\
\hline Ceuta & -1.226 & 10 \\
\hline La Rioja & -1.362 & 10 \\
\hline Region & Land infrastructure & Percentile \\
\hline Castile and Leon & 0.731 & 90 \\
\hline Castile-La Mancha & 0.535 & 90 \\
\hline Andalusia & 0.514 & 90 \\
\hline Aragon & 0.473 & 75 \\
\hline Valencia & 0.466 & 75 \\
\hline Extremadura & 0.391 & 50 \\
\hline Catalonia & 0.353 & 50 \\
\hline Navarra & 0.250 & 50 \\
\hline Murcia & 0.227 & 50 \\
\hline Galicia & 0.210 & 50 \\
\hline Asturias & 0.171 & 25 \\
\hline Balearic Islands & 0.164 & 25 \\
\hline La Rioja & 0.159 & 25 \\
\hline Canary Islands & 0.098 & 25 \\
\hline Cantabria & 0.088 & 10 \\
\hline Madrid & 0.057 & 10 \\
\hline Basque Country & 0.019 & 10 \\
\hline Ceuta & -3.308 & 10 \\
\hline Melilla & -3.372 & 10 \\
\hline
\end{tabular}

Source: Authors' elaboration with data for 2007. 


\section{APPENDIX B}

Description of the various categories of facilities:

- Dry ports are inland areas that receive and dispatch freight that coming from or bound for maritime ports.

- Logistics facilities are defined areas where various operators perform activities related to transport, logistics and distribution of goods for national or international transit.

- Logistics zones are areas linked to ports that provide equipment for storage, logistics and specific facilities for overland, rail and maritime transport. They are generally devoted to maritime freight.

- Centres for exchanging goods are specially defined areas in which various operators perform activities related to transport, logistics and distribution of goods both for national and international traffic, with common services for freight, transport companies and other users of such facilities.

- Intermodal centres are logistics areas for transferring and distributing freight via road haulage and which include a service area for people and vehicles.

- Logistics centres are industrial areas that bring together all the activities related to logistics, transport and the distribution of freight in the broadest sense of the term and which cater for any company seeking a full-service environment for their operations. They are also a node between modes of transport, thus allowing the different modes to work together accordingly.

- Transport centres are specially defined areas where different operators perform activities related to transport, logistics and distribution of goods both for national and international traffic by road.

- Ports are the combination of works, facilities and services provided in the still water area necessary for vessel safety while performing freight loading, unloading and storage operations as well as passenger transit.

- Freight terminals are rail facilities that provide train access and dispatching services to companies.

- Freight terminals at airports are airport facilities where handling agents provide services to airlines and their customers.

- Boarding centres are airport logistics platforms where various operators perform all the activities related to transport, distribution of goods and other logistics operations (storage, handling, order preparation, etc.) for both national and international transit in a specified area. 